\title{
SINTESIS SENYAWA ETILENDIAMIN KALANON MELALUI REAKSI ADISI GUGUS ETILENDIAMIN TERHADAP IKATAN RANGKAP C7-8 DAN UJI AKTIVITAS ANTILEUKEMIA TERHADAP SEL LEUKEMIA L1210
}

\author{
Mochamad Chasani $^{1}$, Eva Vaulina, Y.D ${ }^{1}$, Ponco Iswanto ${ }^{1}$, M. Hanafi ${ }^{2}$ \\ ${ }^{1}$ Program Studi Kimia MIPA, Fakultas Sains dan Teknik, Universitas Jenderal \\ Soedirman, Purwokerto \\ ${ }^{2}$ Puslit Kimia LIPI, PUSPIPTEK, Serpong, Tangerang
}

\begin{abstract}
Calanone is a natural compound which could be isolated from tree bark of Calophyllum biflorum Hend and WS ( 0,37 \% w/w, crude extract) which have been potency as antileucemia drug $\left(\mathrm{IC}_{50}=59,4 \mathrm{ug} / \mathrm{mL}\right)$. Based on the research, the compound can be used as an anti leukemia drug if it value of $\mathrm{IC}_{50}<10 \mathrm{ug} / \mathrm{mL}$. So the aim of this research are in order to get higher calanone activity by modified of double bond carbon-carbon and to obtained several compounds as well which has a higher activity than calanone of its original compound. Several compounds, several compound can be obtained by modified of doble bond carbon-carbon by ethylendiamine group and antileukemia test of the new compound calanone derivatives towards L1210 leukemia cell. The result of the analysis, using thin layer chromatography with eluent methanol:dichlorometane ( $1: 6)$, give $\mathrm{Rf}$ at 0.51 and initial melting point at range $149^{\circ} \mathrm{C}-151^{\circ} \mathrm{C}$. Infra red spectrophotometry and mass spectrometry were used to identify the synthesized product. The result showed that the mass spectra of ethylendiamine calanone give molecular ion at $449\left(\mathrm{M}^{+}-\mathrm{H}_{2} \mathrm{O}, \mathrm{NH}_{3}\right)$ and ions fragmen at m/e 449; m/e 434; m/e 393; m/e 105, m/e 77. Infra red spectra of its compound showed new peaks at $1620 \mathrm{~cm}^{-1}$ and $1063 \mathrm{~cm}^{-1}$. The activity value toward leukemia cell was $\mathrm{IC}_{50}=46,28 \mu \mathrm{g} / \mathrm{mL}$ and its value higther than calanone origin
\end{abstract}

Key word: Calanone, ethylendiamine calanone, in vitro, Antileukemia

\section{PENDAHULUAN}

Penyakit kanker darah (leukemia) merupakan penyakit kanker yang paling banyak dijumpai di Indonesia setelah kanker mulut rahim, kanker hati, kanker payudara, dan kanker paru-paru. Penyakit ini paling sering djumpai pada anak-anak (Siswandono, 2006).

Kalanon adalah senyawa turunan kumarin hasil alam yang diisolasi dari spesies Calophyllum $(0,37 \%$ b/b ekstrak kasar) yang tumbuh di hutan tropis Kalimantan dan Malaysia yang mempunyai potensi sebagai obat antileukemia $(\mathrm{IC50}=59,4 \mu \mathrm{g} / \mathrm{mL})$ (Wibisono, 1998; Chasani, 2003). Upaya yang telah dilakukan guna meningkatkan aktivitas pharmakologi kalanon sebagai obat antileukemia diantaranya adalah dengan memodifikasi struktur molekul kalanon.

Modifikasi struktur kalanon yang telah dilakukan selama ini masih berkisar pada pengubahan gugus karbonil kalanon dan belum dicoba untuk memodifikasi gugus reaktif lain guna peningkatan aktivitasnya. Telah diketahui bahwa efektifitas interaksi obat dan reseptor salah satu faktor yang menentukan adalah efektivitas interaksi antara gugus aktif obat tersebut dengan reseptor. Oleh karena itu dengan melihat fakta bahwa modifikasi gugus karbonil pada karbon nomor 11 
kalanon yang telah dilakukan relatif tidak berpengaruh banyak terhadap peningkatan aktivitas kalanon sebagai obat antileukemia, maka sangat penting dilakukan modifikasi bagian lain dari struktur kalanon ini, mengingat dari aspek kelimpahan kalanon yang relatif cukup besar $(0,37 \%$ b/b) dari spesies Calophyllum (Wibisono, 1997) dan berpotensi sebagai obat antileukemia $(59,4 \mathrm{ug} / \mathrm{mL})$. Bagian reaktif lain dari senyawa kalanon selain gugus karbonil C11 adalah pada gugus ikatan rangkap pada $\mathrm{C} 7-8$.

Mengingat rendemen isolat kalanon dari spesies Calophyllum yang cukup besar dan berpotensi untuk dijadikan obat antileukemia, maka penting untuk dilakukan mengembangkan struktur molekul kalanon melalui modifikasi struktur molekulnya dengan memodifikasi ikatan rangkap C7-8 melalui reaksi adisi dengan gugus yang potensial meningkatkan aktivitas antileukemianya, diantaranya adalah gugus golongan amina. Sebagaimana diketahui bahwa senyawaan pengalkil diantaranya adalah senyawaan golongan amina terbukti mampu meningkatkan aktivitas penghambat leukemia, seperti pada senyawa triptolide yang berasal dari Tripterigium wilfordii Hook F (Yang, et all., 1995: Siswandono dan Sukardjo, 1998).

\section{METODE PENELITIAN}

\section{Waktu dan Tempat Pelaksanaan Penelitian}

Program penelitian tahun pertama ini dilaksanakan dari bulan Maret 2008 sampai dengan bulan Nopember 2008. Lokasi sintesis dan QSAR dilakukan di Laboratorium Kimia Organik, Program Studi Kimia Universitas Jenderal Soedirman, Purwokerto. Analisis struktur molekul dilakukan di Laboratorium Instrumentasi UGM, Yogyakarta. Uji aktivitas antileukemia dilakukan di Laboratorium PATIR, BATAN, Jakarta.

\section{Materi dan Alat}

Bahan-bahan yang digunakan untuk sintesis adalah: Etildiamin, n-Heksana, etil asetat, $\mathrm{H}_{2} \mathrm{O}$, diklorometana, kloroform, aseton, metanol, plat KLT, silika gel $\mathrm{G}_{60}$, Na-sulfat anhidrat, senyawa kalanon asal (dari Laboratorium Kimia Bahan Alam, Puslit Kimia LIPI Serpong). Alat-alat yang digunakan adalah: satu unit alat refluks; rotaryevaporator; plat KLT; gelas piala $250 \mathrm{~mL}, 500 \mathrm{~mL}, 1 \mathrm{~L}$; erlenmeyer $250 \mathrm{~mL}, 500 \mathrm{~mL}, 1 \mathrm{~L}$; spatula; batang pengaduk; satu unit alat penentu titik leleh; botol polietilen, tripleneck, penangas minyak, heatingmagnetic stirrer, dan kolom kromatografi.

\section{Prosedur}

\section{Sintesis dan uji aktivitas etilendiamin kalanon}

Sampel sebanyak $106 \mathrm{mg}$ dimasukkan dalam labu leher tiga, 100 $\mathrm{mL}$, yang dilengkapi stirer dan pengaduk magnetik dan ditambahkan $50 \mathrm{~mL}$ metanol dan $10 \mathrm{~mL}$ etilendiamine Campuran reaksi diaduk selama 2 jam. Setelah itu campuran reaksi diekstraksi dengan 15 $\mathrm{mL}$ air dan $15 \mathrm{~mL}$ diklorometan sebanyak tiga kali. Fraksi diklorometan selanjutnya diuapkan pelarutnya sampai tinggal $1 / 4$ nya dan ditambahkan $\mathrm{Na}_{2} \mathrm{SO}_{4}$ anhidrat dan disaring. Selanjutnya dilakukan KLT menggunakan eluen aseton: n-heksan: etil asetat 1: 2: $1(\mathrm{v} / \mathrm{v})$. Produk sintesis dalam fraksi diklorometan ini dimurnikan dengan rekristalisasi 
menggunakan metanol dengan sedikit diklorometan (1:4) dan proses rekristalisasi dilakukan beberapa kali. Kristal hasil diuji lagi menggunakan KLT dengan eluen yang sama seperti di atas. Produk sintesis yang telah murni ini selanjutnya dikeringkan dan ditimbang.

Langkah selanjutnya adalah dilakukan uji titik leleh, analisis struktur molekul menggunakan spektrometer FT-IR, MS dan uji aktivitas antileukemianya terhadap sel leukemia L1210.

\section{HASIL DAN PEMBAHASAN}

Modifikasi atau manipulasi struktur molekul senyawa isolat produk alam yang telah diketahui aktivitas farmakologinya melalui sintesis senyawa turunannya adalah suatu langkah yang bertujuan memperoleh senyawa baru yang diharapkan mempunyai aktivitas lebih tinggi, dibandingkan senyawa isolat asal. Langkah ini cukup efektif dan efisien guna memperoleh senyawaan obat baru dan merupakan kegiatan penelitian yang berbasis pemanfaatan produk alam.

\section{Sintesis}

Senyawa produk sintesis yang telah murni pada reaksi etilendiaminasi gugus ikatan rangkap pada $\mathrm{C} 7-8$ ini berupa padatan kristal kuning kemerahan dengan rendemen sebesar 23,4\% (b/b) dengan titik leleh 149 $151^{\circ} \mathrm{C}$. Nilai Rf etilendiamin kalanon produk hasil KLT menggunakan eluen metanol:diklorometan (1:6) diperoleh sebesar 0,51 yang jauh lebih kecil dibandingkan Rf kalanon standar sebesar 0,93. Hal ini menunjukkan bahwa etilendiamin kalanon produk memiliki kepolaran yang lebih besar dibandingkan senyawa kalanon asal.
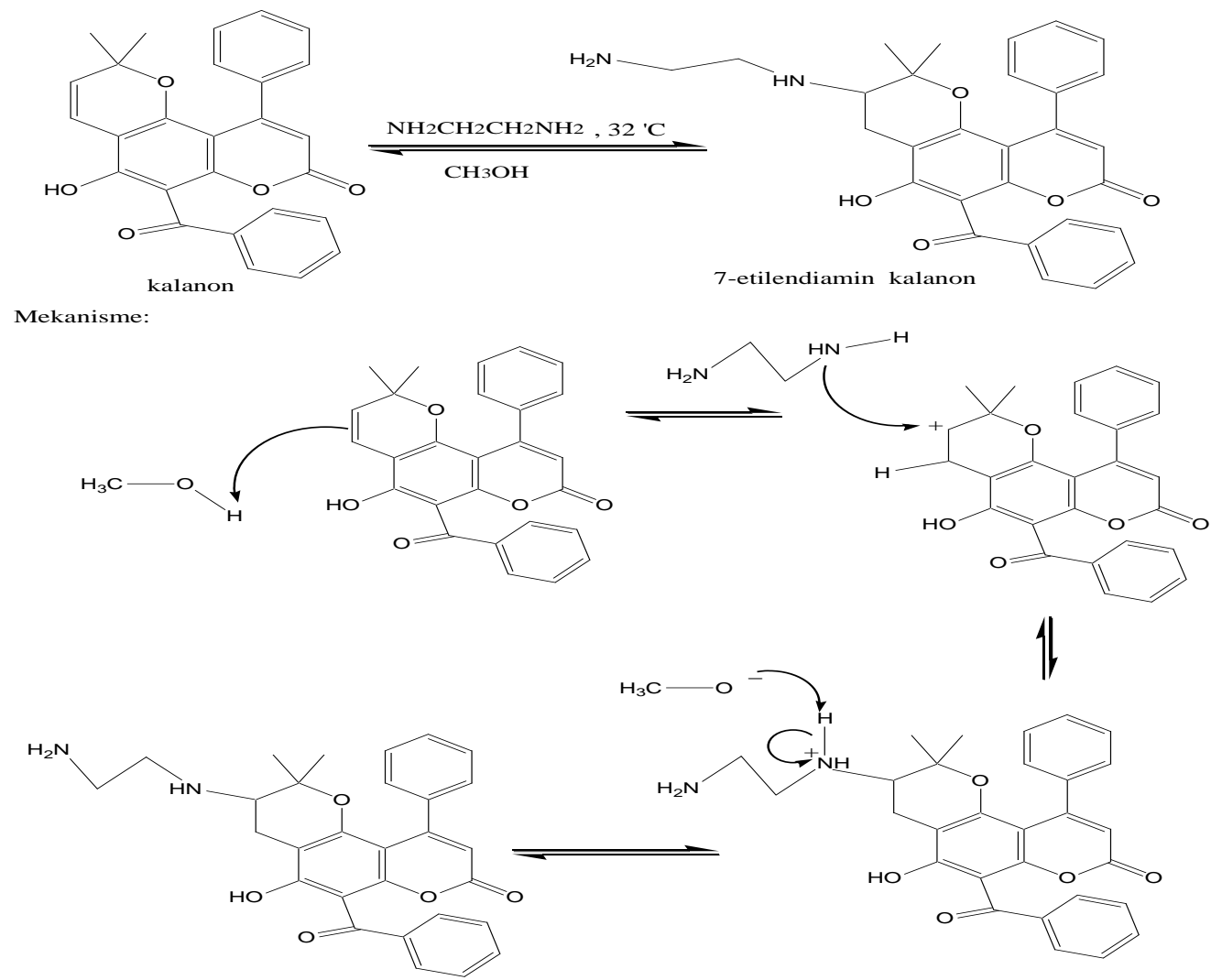

Gambar 1. Mekanisme reaksi etilendiaminasi kalanon 
Reaksi adisi oleh gugus etilendiamin pada senyawa asal kalanon terhadap ikatan rangkap pada posisi C7 dan C8 seperti pada Gambar 1 dimulai dengan terbentuknya ion positif pada C7 kalanon akibat adisi elektrofilik ion $\mathrm{H}^{+}$dari metanol. Ion positif $\mathrm{C} 7$ yang tidak stabil ini menginduksi serangan nukleofilik dari pasangan elektron bebas gugus amin dari etilen diamin dan diikuti lepasnya $\mathrm{H}^{+}$dari ion gugus amin dengan bantuan anion metoksida. $\left(\mathrm{CH}_{3} \mathrm{O}^{-}\right)$.

Data spektum infra merah dan spektrometri massa

Data spektrum infra merah

Hasil analisis FT-IR terhadap senyawa etilendiamin kalanon produk menunjukkan hilangnya pita serapan pada bilangan gelombang $1790 \mathrm{~cm}^{-1}$ yang hal ini muncul pada senyawa kalanon. Pita serapan ini merupakan karakter dari alkena siklik yang terdapat pada ikatan C7 dan C8. Hilangnya serapan ini pada spektrum senyawa kalanon sulfonat menunjukkan bahwa ikatan rangkap C7-8 telah mengalami reaksi adisi dan menjadi ikatan tunggal. Uluran N-H kopel kembar pada bilangan gelombang $3350-3450 \mathrm{~cm}^{-1}$ yang merupakan daerah gugus amin primer dari spektrum ini tidak nampak. Hal ini disebabkan puncak kopel yang khas sedang dan berakibat tertutupi oleh adanya uluran $\mathrm{O}-\mathrm{H}$ fenolik yang melebar dan sedang dari kalanon pada daerah sekitar $3300-3450 \mathrm{~cm}^{-1}$. Meskipun demikian dengan terdapatnya pita serapan pada $1620 \mathrm{~cm}^{-1}$ yang merupakan pita tekukan N-H (menggunting) dan pita serapan pada $1063 \mathrm{~cm}^{-1}$ yang merupakan pita uluran $\mathrm{C}-\mathrm{N}$, menunjukkan bahwa gugus etilen diamin telah mengadisi karbon pada $\mathrm{C} 7$ dari ikatan rangkap C7-8 senyawa kalanon asal. Spektrum FT-IR etilendiamin kalanon ditampilkan pada Gambar 2.

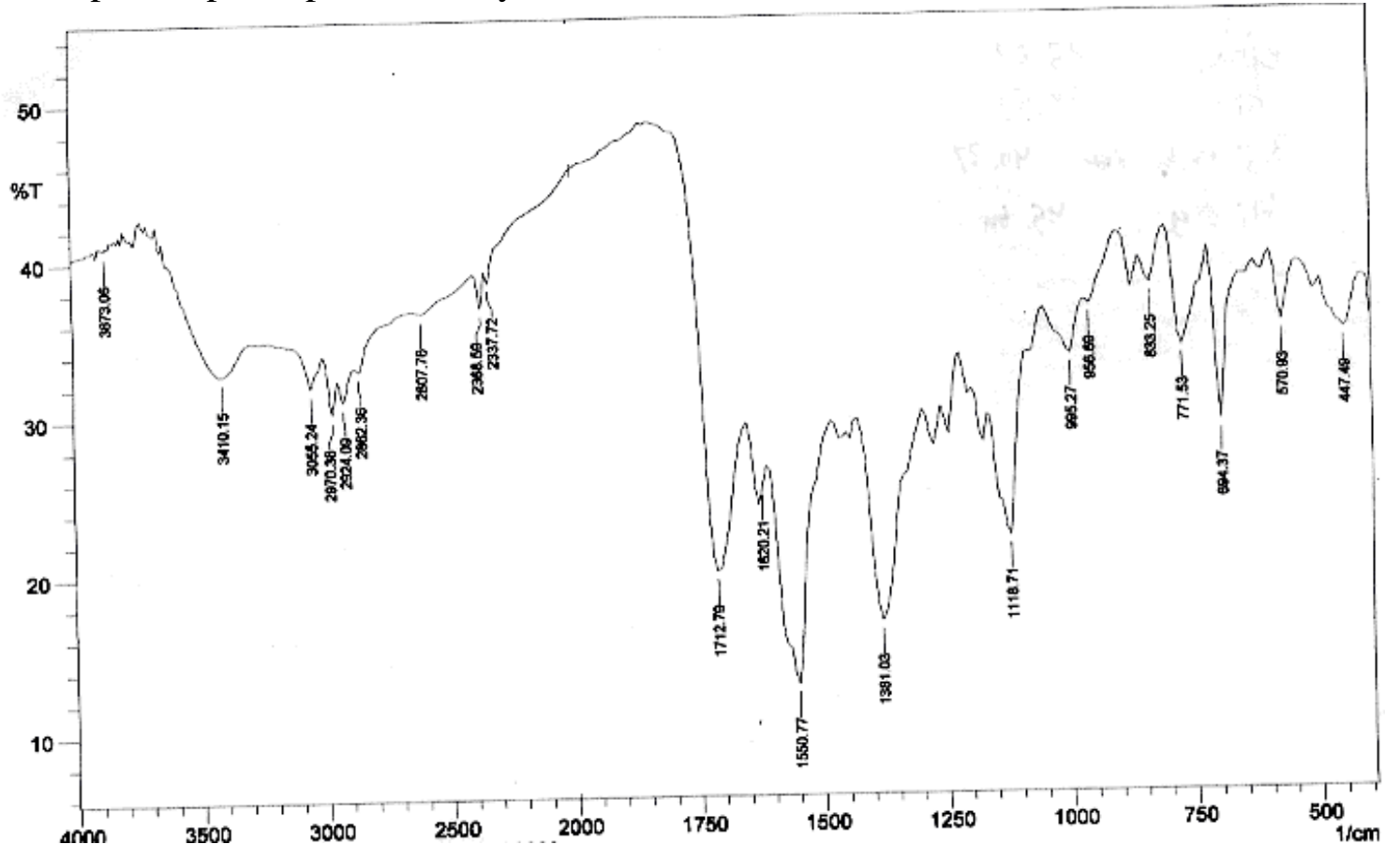

Gambar 2. Spektrum FT-IR senyawa etilendiamin kalanon 


\section{Data spektrometri massa}

Hasil identifikasi MS senyawa etilendiamin kalanon muncul puncak pada $\mathrm{m} / \mathrm{e} 449$ yang merupakan puncak dari $\mathrm{M}^{+}-\mathrm{H} 2 \mathrm{O}-\mathrm{NH} 3$. Puncak ion molekul $\left(\mathrm{M}^{+}=484\right)$ dari spektrum MS ini tidak muncul adalah akibat lepasnya dua molekul netral kecil yakni $\mathrm{H}_{2} \mathrm{O}$
(BM 18) dan $\mathrm{NH}_{3}$ (BM 17). Adapun puncak khas lain adalah m/e 449; m/e 434; m/e 393; m/e 105 dan m/e 77. Spektrum massa etilendiamin kalanon ditampilkan pada Gambar 3. Sedangkan pola fragmentasinya sebagaimana terlihat pada Gambar 4.

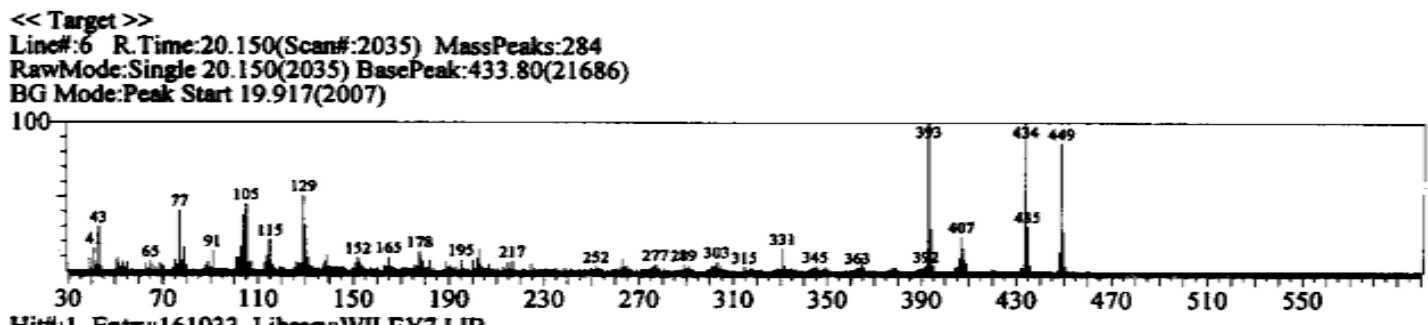

Gambar 2. spektrum MS senyawa etilendiamin kalanon
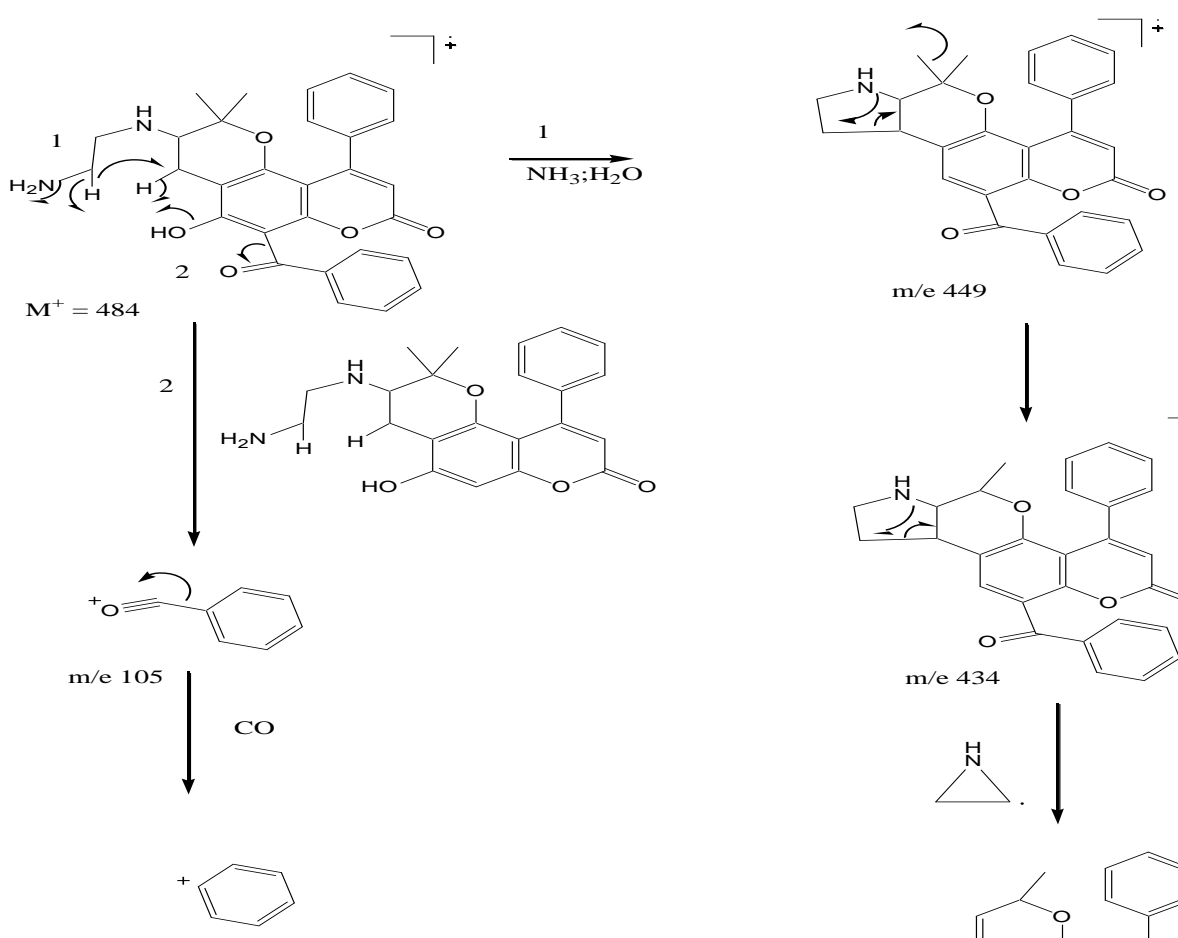

$\mathrm{m} / \mathrm{e} 77$

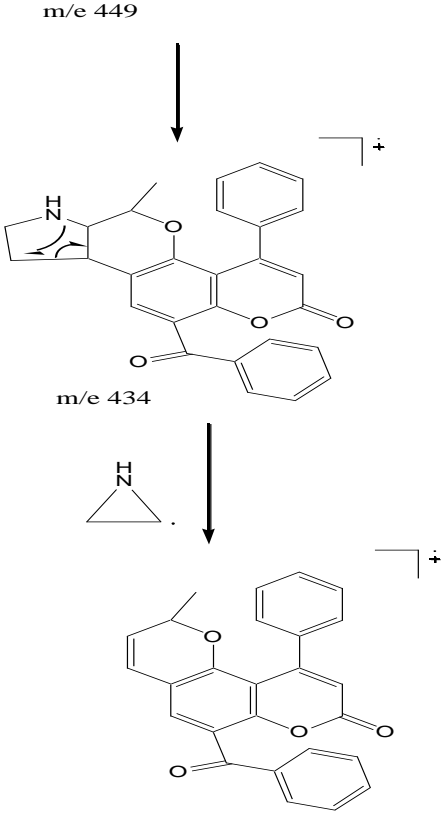

m/e 393

Gambar 3. Pola fragmentasi spektrum massa senyawa etilendiamin kalanon 


\section{Data aktivitas anti leukemia terhadap sel leukemia L1210}

Uji aktivitas antikanker dari empat senyawa hasil sintesis ini dilakukan dengan uji sitotoksisitas in vitro menggunakan sel leukemia L1210. Hasil pengamatan uji antikanker yang berupa nilai $\mathrm{IC}_{50}$ yang menunjukkan aktif atau tidaknya suatu sampel dalam menghambat pertumbuhan sel kanker. Nilai $\mathrm{IC}_{50}$ dalam satuan ppm (ug/mL) dari senyawa uji menunjukkan konsentrasi senyawa uji yang diperlukan untuk menghambat $50 \%$ pertumbuhan sel kanker. Makin kecil nilai $\mathrm{IC}_{50}$, makin aktif senyawa yang diujikan dalam menghambat pertumbuhan sel kanker dan suatu senyawa dikatakan aktif sebagai senyawa anti kanker jika nilai Nilai $\mathrm{IC}_{50}$ lebih kecil dari 10 ppm.

Hasil uji sitotoksisitas keempat senyawa hasil sintesis yakni etilendiamin kalanon terhadap sel leukemia L1210 dan nilai Nilai IC $_{50}$ senyawa kalanon asal ditampilkan pada Tabel 1.

Tabel 1. Data nilai $\mathrm{IC}_{50}$ senyawa turunan kalanon hasil sintesis dan standar terhadap sel leukemia L1210

\begin{tabular}{clc}
\hline No & \multicolumn{1}{c}{ Senyawa } & $\begin{array}{c}\text { Nilai } \mathbf{I C}_{50} \\
(\mathbf{u g} / \mathbf{m L})\end{array}$ \\
\hline 1 & Kalanon & 59,4 \\
2 & Etilendiamin & 39,57 \\
& kalanon & \\
\hline
\end{tabular}

Berdasarkan Tabel 1 terlihat bahwa terdapat perbedaan aktivitas antileukemia antara senyawa kalanon asal dan etilendiamin kialanon. Berbeda dengan penelitian sebelumnya yakni pada senyawa turunan kalanon hasil memodifikasi gugus karbonil pada $\mathrm{C} 11$, yang secara garis besar aktivitas antikanker senyawa- senyawa turunan kalanon tersebut hampir dikatakan tidak meningkatkan aktivitas antikankernya malah semakin melemahkan aktivitasnya.

Fakta di atas menunjukkan bahwa bagian ikatan rangkap C7-8 kalanon berperan lebih besar sebagai salah satu sisi aktif kalanon dalam menghambat pertumbuhan kanker, khususnya leukemia dibandingkan dengan bagian gugus karbonil pada C11 kalanon. Di sisi lain gugus substituen yang paling berperan dalam meningkatkan aktivitas antikanker kalanon pada sisi aktif C7-8 adalah gugus golongan amina, hal ini dapat dibuktikan dengan nilai $\mathrm{IC}_{50}$ senyawa etilendiamin kalanon yang cukup lebih tinggi dibandingkan senyawa kalanon standar.

\section{KESIMPULAN}

Berdasarkan hasil penelitian diperoleh beberapa kesimpulan sebagai berikut:

1. Diperoleh senyawa baru turunan kalanon yakni etilendiamin kalanon, hasil adisi menggunakan molekul etilendiamin terhadap gugus ikatan rangkap pada $\mathrm{C} 7-8$ kalanon dengan nilai $\mathrm{IC}_{50}=$ $39,57 \mathrm{ug} / \mathrm{mL}$

2. Modifikasi gugus ikatan rangkap C7-8 kalanon terbukti mampu meningkatkan aktivitas antileukemia kalanon, hal ini menunjukkan bahwa gugus ikatan rangkap C7-8 kalanon berperan sebagai sisi aktif kalanon dalam fungsinya sebagai obat antileukemia.

3. Gugus amin diduga adalah gugus yang potensial berperan meningkatkan interaksi obat dan reseptor pada senyawa kalanon 


\section{UCAPAN TERIMA KASIH}

Pada kesempatan ini penulis mengucapkan terima kasih yang sebanyak-banyaknya kepada :

1. Direktorat Jenderal Pendidikan Tinggi, Jakarta

\section{DAFTAR PUSTAKA}

Al-Mondhiry, H. 1984. Calanone, A Novel Coumarin from C. testimannii. Am. Journal Hematology. 16:193-202.

Angerer, E.; M Kager; K. Kervin C. Benefield; A Umerane; AlbainyJenei; QS. Zhao; dan MB. Khazaeli. 1994. Journal Cancer Res.Clin.Oncol. 120 (suppl): S3S10..

Berkada, B.; H. Bouffard-Eyubaglu; dan U. Derman. 1983. Agents Actions. Journal of Carcinogenesis. 13(1): 50-51.

Chasani, M. 2002. Sintesis Senyawa Turunan Kalanon dan Uji Aktivitas Biologinya. Tesis. Program Pascasarjana Universitas Indonesia,Jakarta.

Dewi, D. K. 2001. Esterifikasi Senyawa Kalanon serta Uji Aktivitas Antimikroba Terhadap E. coli, B. subtilis, dan C. albicans. Skripsi. Fakultas Farmasi Universitas Indonesia, Jakarta.

Kier, L. B., M. S. Tute, and O. W. Foye. 1989. Principle of Medicinal Chemistry : Theoritical Aspect of Drug Design. Lea and Febiger. Philadelpia

Made, S. 1998. Bioasai In Vitro dengan Sel Leukemia L1210, Sebuah Metode Skrining Zat Antitumor dari Bahan Alam. Prosiding
2. Lembaga Penelitian Universitas Jenderal Soedirman, Purwokerto

3. Kimia LIPI, PUSPIPTEK , Serpong

4. Badan Tenaga Atom Nasional

Seminar Bioteknologi Kelautan Indonesia, Jakarta.

Mc. Culloch, P dan ED George. 1988. Coumarin Derivatives Inhibition. Br Journal Cancer. 58: $158-162$.

Mutschler, E. 1986. Dinamika Obat. Terjemahan oleh Widianto. 1991. Penerbit ITB. Bandung.

Sardjoko. 1993. Rancangan Obat. UGM Press. Yogyakarta.

Sari, M. P. 2001. Esterifikasi Senyawa Kalanol serta Uji Aktivitas Antimikroba Terhadap E. coli, B. subtilis, dan C. albicans. Skripsi. Fakultas Farmasi Universitas Indonesia, Jakarta.

Siswandono dan B. Soekardjo. 1998. Prinsip-Prinsip Rancangan Obat, Cetakan Pertama. Airlangga University Press. Surabaya.

Wibisono, L. K. 1997. Penentuan Struktur Molekul Derivat Kumarin dari Kulit Batang C. biflorum Hend \& WS dan Pengaruhnya terhadap Pertumbuhan in vivo Tumor Kelenjar Susu Mencit $\mathrm{C} 3 \mathrm{H}$. Tesis. Magister Sains Ilmu Kimia Universitas Indonesia, Jakarta. 